\title{
Environmental citizenship and public attitudes to hydrogen energy technologies
}

Rob Flynn*, Paul Bellaby and Miriam Ricci

Institute for Social, Cultural and Policy Research, University of Salford, Salford, UK

\begin{abstract}
Some of the principal arguments in the debate about environmental citizenship are examined with reference to the development of hydrogen energy systems. In particular, qualitative evidence is drawn from a study of public attitudes towards hydrogen energy technologies and their perceived risks and benefits. Using data from focus groups in three areas of the UK, it is argued that while there is awareness of the importance of energy issues, opinions about innovation using hydrogen are generally neutral, and there is little indication of the collective and solidaristic values said to characterise environmental citizenship.
\end{abstract}

\section{Introduction}

In contemporary advanced industrial societies, political concern about the impact of global warming and climate change has begun to intensify. Despite some evidence that the general public is aware of environmental problems and a crisis over fossil fuels, evidence that this is resulting in major changes in behaviour (for example, in energy use) is not compelling. Some commentators have optimistically suggested that the conditions of modern citizenship can be extended to incorporate ecological rights and responsibilities, in the form of environmental citizenship. Here we first briefly review concepts of 'environmental citizenship' and the linkages between citizenship, environmental risks and sustainability. We then examine qualitative evidence about public perceptions of the energy crisis, hydrogen technologies and sustainability. Hydrogen has been identified as potentially providing a radically new and environment-friendly energy system. Findings from focus groups are presented about: awareness of global warming, environmental problems and energy; responsibility for behaviour change; and attitudes towards hydrogen. It is argued that while the level of public awareness of environmental

*Corresponding author. Email: r.flynn@salford.ac.uk 
(and specifically energy) issues is generally high, there is little sign of a substantive commitment to the solidaristic values ascribed to environmental citizenship. In relation to hydrogen energy, environmental citizenship is only latent and provisional, and certainly falls short of 'ecological citizenship'.

\section{Citizenships}

To understand the meaning of environmental or ecological citizenship first we must briefly consider some of the wider debate about the construction of modern citizenship. Bryan Turner's $(1990,2001)$ cogent critique of T.H. Marshall's concept of citizenship provided a synthesis of its changing scope and continuing relevance. Turner (1990) identified citizenship as a central issue for social integration and social solidarity, and emphasised the role of social struggles and conflict in its creation and maintenance. He noted that national boundaries around citizenship have become less important as a result of globalisation. Turner (2001) further developed his critique of Marshall's concept, in which social rights were the core. Like other commentators, Turner examined the significance of duties and obligations, and their connection with 'an inclusionary process involving some re-allocation of resources and an exclusionary process of building identities on the basis of a common or imagined solidarity' (Turner 2001, p. 192). In particular, he argued that a new regime of rights had emerged with changed economic and global environmental conditions. New forms of citizenship had developed, 'driven by a common problem of modern society, namely the relationship between the human body and the environment' (p. 204). Social risks created by new technology, environmental pollution, and the spread of AIDS, were examples Turner cited in which new forms of citizenship had begun to emerge. Thus, rights to a safe environment were not seen as merely part of the agenda for environmental social movements, but part of much wider demands 'to protect humans from the negative consequences of economic growth and technology on their health and safety' (p. 206).

In this, Turner was extending the important argument that Marshallian citizenship required adaptation to current contexts, particularly in relation to environmental issues and the wider debate about 'risk society' highlighted by Beck (1992). Newby (1996) also strongly urged that Marshall's concept of citizenship should be modified to deal with needs, rights, duties and obligations arising in relation to the environment and sustainability. For Newby, 'environmental citizenship' linked socio-economic with scientific-technological issues, especially global threats such as the depletion of natural resources and degradation of the environment. Newby (1996, p. 218) proposed that 'we are all, therefore, environmental citizens now', and this raised classic problems of cooperation, interdependency and social order. Somewhat earlier, van Steenbergen (1994) had noted that Marshall's concept of citizenship was fundamentally about levels of material well-being, and argued that contemporary citizenship had a fourth dimension (to be added to civil, political and 
social rights) comprising environmental or ecological citizenship. This, he argued, was underwritten by responsibilities for the natural world and restraints on action. Dahrendorf (1994, p. 18) too had also acknowledged that while it was difficult to 'stipulate an entitlement for all of us as world citizens to a liveable planet, and thus to actions which sustain it, ... something of this kind may well belong on the agenda of citizenship'.

\section{Environmental citizenship}

Various writers have observed that social scientists have paid insufficient attention to the growing importance of ecological risks and environmental issues. From different standpoints, Dickens (1992), Newby (1991) and Beck (1995) criticised sociology for its neglect of the natural and physical environment, and each urged it to overcome the conventional 'nature/society' dichotomy. Barry (1999) advocated a 'relational' approach to the environment and nature, and argued that the 'greening' of social theory entails greater awareness of the ecological embeddedness and biological embodiedness of humans. He also noted that sustainability was a corollary of such an approach: concern for nature and environment inevitably involved a future orientation and sense of obligation to future generations.

Irwin (2001) argued for a critical distance on 'sustainability discourse'. Thus:

the linkages between a sense of environmental crisis, calls for inter-generational equity and the notion of togetherness are not simply given but instead are actively constructed ... the environmental crisis does not simply impact upon our lives but is mediated and reconstructed within a host of social institutions and through ... kinds of discourse formation ... (Irwin 2001, p. 47)

Irwin went on to advocate much closer attention to the experiences, 'framings' and locally mediated understandings of environmental issues and sustainability.

Similarly, Yearley (2005) has argued that ideas about sustainable living have been limited because they neglect sociological analysis of what constitutes a 'sustainable' life. Yearley acknowledged that as sustainable development is defined as meeting present needs without jeopardising the capacity of future generations to meet their own needs, there has tended to be a preoccupation with 'technical' (environmental) questions and economic arrangements, but very little attention paid to cultural practices and social institutions. The crucial questions about environmentalism and sustainability, Yearley claims, are ones about social order, and distributional and equity issues, and people's understandings and actions around such issues. Using the example of energy resources, Yearley notes that much research has focused on energy conservation and new sources of energy, and some aspects of consumer behaviour, but questions of how people regard the ownership, trading and use of energy as a commodity and as a social resource are rarely debated. Thus 'the social 
institutions of sustainable societies are missing - or are implicit and unexamined' (Yearley 2005, p. 180).

The concepts of environmental and ecological citizenship have gained widespread currency in political theory but to a much lesser extent within the disciplines of social policy and sociology. In practice, they have been embraced politically by numerous environmental social movements and lobby groups. The rapid and extensive growth of the 'Green' movement and green political theory (see, for example, Dickens 1992, Barry 1999, Dean 2001, Yearley 2005) has forced social scientists to re-think their conceptual frameworks and to address much more systematically issues beyond the conventional or traditional approaches to questions of life chances primarily determined by the labour market and welfare institutions.

Dobson has extensively debated the significance of these issues in much recent writing. Dobson (2003) noted that current environmental problems are not confined to nation-state boundaries, and that globalisation itself produces new kinds of ecological asymmetries both within and between states. Dobson (2003) also distinguished a model of 'environmental' citizenship which stresses entitlements and rights, from 'ecological' citizenship which stresses duties and responsibilities, based on obligations. Both, he claims are valid, and are complementary, oriented towards the achievement of a sustainable society. Ecological citizenship seeks a just distribution of (ecological) resources. Dobson and Valencia Saiz (2005) take these arguments further. They propose that ecological citizenship must be based on the recognition that sustainability implies commitment to the idea of 'the common good' (versus self-interest) and that in practice this requires a major shift in attitudes and behaviour. Bell (2005) identifies environmental citizenship as deriving from the 'liberal' model of citizenship, comprising basic environmental rights and duties. These rights minimally include environmental goods such as clean air and water, but also extend to procedural rights to be included in decision-making about the environment. Duties include the obligation to comply with environmental laws but also to justify choices about lifestyles which affect the environment.

Dobson and Bell (2006) analyse environmental citizenship theory, and differentiate the 'liberal' approach to rights, as compared with the 'republican' approach focused on responsibilities. Each problematises 'virtues' such as willingness to work for the common good and the connection between individual actions and their collective impact. Barry (2006) advocates the 'republican' approach and applies it to what he terms sustainability citizenship. This goes beyond environmental citizenship because it is not restricted solely to environmental issues - instead it raises questions about the structural causes of environmental degradation and implies a commitment to a different type of (sustainable) society. There has been some disagreement about whether Dobson's concept of ecological citizenship is distinctive (since it does not entail membership of a polity), and whether his advocacy of a normative concept of ecological citizenship is convincing (see Dobson 2006, Hayward 2006a, 2006b). However, there is an emerging consensus that the concepts of 
environmental and ecological citizenship highlight important questions about solidaristic values and behaviour associated with sustainability. Most importantly, as Dobson and Valencia Saiz (2005, p. 128) note, the citizenship approach to sustainability draws on the core idea of the 'common good'.

To summarise, this brief review has indicated a number of significant interrelated issues. First, people's life chances are affected by environmental processes and may be influenced by the possible emergence of 'environmental' or 'ecological' citizenship. People's structured opportunities are partly conditioned by the availability and distribution of scarce natural resources (for example, fossil fuels and the supply of energy) and the overall constraints of global environmental change. They are also directly and indirectly affected by private action and state intervention, reflected in consumer attitudes, producer behaviour, and regulatory regimes in particular spheres (for example, pollution, energy use, recycling, etc.). Second, insofar as 'green' environmental awareness has developed, notions of environmental/ecological citizenship presume changes in social attitudes and political belief - and behaviour oriented towards duties and obligations connected with the 'common good'. For example, if access to and use of energy resources is a major concern for people, how far are they prepared to alter their behaviour to safeguard those resources, or accept redistribution among competing citizens, or tolerate rationing by price and/or state controls? How far are they willing to support the development of new energy technologies which are being introduced to cope with climate change or global warming but which may involve potentially new risks and benefits which themselves may be unequally distributed? In energy policy and related environmental issues, does individual self-interest coexist with expressed concern for collective welfare, and how might this affect environmental citizenship and sustainability?

Many studies have previously identified contradictions between 'egoism' and 'altruism' in environmental policy, and the tensions between the citizen and consumer role. The dissonance between people's beliefs about problems in the environment and their preparedness to change behaviour (for example, to reduce energy use) is well established (Dobson and Bell 2006, Nash and Lewis 2006). Berglund and Matti (2006), for example, provide evidence (from Sweden, about the recycling of waste) that the civic virtue associated with 'the common good' is tempered by rational economic incentives. They argue that in practice, people have 'multiple preference orderings' which are applied differentially in different contexts. Data from the large-scale British Social Attitudes Survey have demonstrated a disconnection between environmental awareness and action. The incidence of environmentally-friendly behaviour was found to be far lower than people's level of environmental concern. This was explained, partly, by people's sense that they had little capacity to act even if they felt a kind of responsibility, as well as a broader distrust of industry and government, and an anxiety that not everyone would 'do their bit'. In general, attitudes to the environment were characterised by contradictoriness, confusion and inconsistency (Christie and Jarvis 2002). 
The problems of breaking out of an economy totally dominated by fossil fuels, and difficulties in bringing about major changes in people's lifestyles towards sustainability, have been noted by many other commentators (see Murphy and Cohen 2001). One important recent report on moves towards sustainable consumption and social justice described the current inertia, expressed in a prevailing public attitude of 'I will if you will' (Sustainable Development Commission 2006). However, at the 'micro' level, the apparent gap between attitude and action cannot be explained solely in terms of lack of information. Hobson $(2001,2003)$ showed in a detailed qualitative study of household consumption and lifestyles, that the limits on people's willingness to change is partly linked with specific discourses or rhetorics about consumption and the environment, and partly to do with the deeply-embedded nature of everyday practices.

This was also highlighted much earlier by Macnaghten and Urry (1998). Using focus groups about people's knowledge of 'nature' and the environment, Macnaghten and Urry found that people's beliefs and attitudes were ambivalent and contradictory. 'Environmentalism' had diverse and multiple meanings, and such meanings were highly contingent on people's local experiences and cultural practices. Sustainability issues entailed ontological questions which were seen as very challenging for people's sense of identity and group membership. Perhaps most significantly, they showed that when presented with different scenarios and standpoints, people adopted contradictory positions, depending on how the issue was 'framed'. Thus, in connection with certain environmental controversies, the same issues were understood in different ways when those issues were presented in different ways. Macnaghten and Urry (1998, p. 229) further concluded that groups 'did not sense that personal individual actions were likely to make a difference', and that 'collective action was unrealistic, given people's sense of the prevalence of "short-termism" within the state and business'. Although there was evidence of environmental concern, there was little indication of adjustments in lifestyle: 'most people were not radically restructuring their lives or actively engaged in environmental protest' (1998, p. 231).

Given this background, how might people now regard a potential transformation in the energy system which appears to offer environmental benefits but which also requires substantial changes in lifestyles and infrastructures? The next section of the paper examines public perceptions of hydrogen energy technology and some of the implications of a move to a hydrogen economy, to explore how far evidence of attitudes supporting environmental citizenship can be discerned.

\section{Attitudes and beliefs about energy and hydrogen technologies}

In the context of rapid depletion of fossil fuels (coal, natural gas, oil) and concern about climate change and global warming, governments in the major industrial capitalist countries have been investigating the potential 
contribution of alternative or renewable energy sources, and also the feasibility of using hydrogen as an energy carrier. Hydrogen is the most abundant element in the universe; it can be produced by splitting water into hydrogen and oxygen, and can be derived from electricity (from any source, including nuclear energy) or from reforming gas (from natural gas, and methane from biomass). Hydrogen has been frequently described as 'clean' and 'green' and non-polluting. It can be used in fuel-cell vehicles (where the only immediate waste is water vapour), in localised combined heat-and-power systems for buildings, in mobile applications (such as laptops) and in a variety of other applications. Rifkin (2002) claimed that the widespread introduction of hydrogen energy technologies could revolutionise the economy and social structure, as it might enable the decentralised local generation of electricity - it might 'democratise' energy production.

Hydrogen is not a fuel as such, but an energy carrier. The principal concerns among technical experts and energy economists are its infrastructure investment costs and relative efficiency, possible hazards and safety regulation (see Flynn et al. 2006, Hennicke and Fischedick 2006, McDowall and Eames 2006, Ricci et al. 2007a, 2007b). Major international bodies, energy agencies and private corporations have committed significant investment expenditure in research and development of hydrogen energy systems (European Hydrogen and Fuel Cell Technology Platform 2005, United Nations 2006). The major advantages claimed are reduced greenhouse gas emissions and improved security of supply. However, there are still significant uncertainties about the performance and reliability of fuel-cell technologies, about the overall feasibility and efficiency of production, distribution and storage systems (e.g. as a gas or liquid there are highly demanding requirements about pressure and temperature). There are also questions about the public's perceptions (and acceptability) of hydrogen's hazards, risks and benefits. Technological innovation is in its earliest stages, with, for example, prototype hydrogen fuel-cell vehicles (cars and buses) now being introduced, and other applications under development.

To investigate public perceptions of the emerging 'hydrogen economy' we carried out focus groups with members of the general public. Three areas in the UK - Teesside, south west Wales, and London - were selected for detailed study, based on the knowledge that there were already commercial production and storage facilities for hydrogen in situ and/or that in those areas, energy agencies, private companies and local authorities had embarked upon the introduction of hydrogen energy-based technologies. Given the fact that hydrogen energy is still a relatively 'unknown' and emergent technology, it was decided that large-scale survey methods were inadequate and inappropriate to gauge the extent of public awareness of, and attitudes to hydrogen energy. Instead, focus groups were used to explore people's understandings of energy and environmental issues and their attitudes towards new hydrogen technologies. In total, nine groups were held during October-December 2005: four in Teesside, three in London and two in Wales. Further 
methodological details and results from this study have been published elsewhere (Ricci et al. 2007a, 2007b).

Members of the public were recruited through local authorities' public consultation panels; in these areas, there were already-existing 'citizens panels' drawn from a representative sample of the local population. The focus groups for this study were mixed in terms of age, gender, ethnicity and socio-economic group. They were specifically recruited on the basis that they did not have scientific or technological background, or close familiarity with energy technologies. Groups varied in size from six to (in one exceptional case) 13 members. Meetings were facilitated by the authors, and lasted oneand-a-half hours. Discussions were tape-recorded; subsequent to transcription, thematic analysis was carried out independently by each team member, and then through a process of validation by triangulation (Barbour and Kitzinger 1999, Bloor et al. 2001). Focus group members were first asked to indicate whether they were aware of general issues about the environment, energy, global warming and so on, and then were asked to consider different types of energy source; they were asked if they had heard of hydrogen energy, and then shown visual materials and given brief simplified explanations of hydrogen technologies. The discussion below is based on qualitative data analysis of the discussions about 'the environment', 'sustainability' and issues which relate to hydrogen energy and environmental citizenship. As is conventional in reporting focus group data analysis, findings are summarised for groups as a whole, and then illustrative quotations are provided.

There were some consistent and general findings from all of the focus groups in each of the three areas. First, people had high levels of awareness of problems associated with climate change and global warming; they were aware of greenhouse gases and the effects of pollution. Many participants characterised these problems in terms of extremes in weather patterns, and referred to perceived increases in air pollution from road transport. Second, people were very aware of a crisis over the supply of fossil fuels, and were especially knowledgeable about (and concerned by) recent increases in fuel (gas, electricity, petrol/diesel) prices. Third, these concerns were frequently linked with anxiety about and criticism of the international political situation, and their recognition of dependency on foreign states for future supplies. Fourth, in general, while most people could describe some of the properties of hydrogen (e.g. a gas, abundant, potentially explosive, etc.) knowledge about hydrogen as an energy carrier was limited. Fifth, public perceptions of hydrogen were neither entirely positive nor completely negative. People always framed their views about hydrogen and its possible uses in terms of their own experiences and in relation to the local context for example, whether there was a history of employment in local industries related to, or similar to, hydrogen production (coal mining, petrochemicals). Sixth, people expressed opinions and asked questions about hydrogen within a broad framework of concern about the natural environment and made 
explicit comparisons with other sources of energy. Seventh, it was evident that they were willing and able to discuss energy issues in the context of their personal beliefs and values. While concerns about potential hazards and risks to safety were voiced, these did not appear to form the basis of outright opposition or rejection of hydrogen technologies. The dominant presumption was that hydrogen energy technologies will have been thoroughly tested and systems 'engineered' before their widespread introduction. In almost all the focus group meetings, participants indicated that the decision to adopt these new technologies would be determined by trade-offs between cost or price, 'usability' and convenience, safety, and environmental benefits. Finally, a general finding was that participants shared a distrust of government (and also to some extent, business and industry) in relation to their willingness to genuinely accommodate citizen or consumer views about energy.

More specifically, the following observations from different groups in the three areas illustrate their views about awareness of global warming, responsibility for behaviour change and hydrogen energy technologies.

\section{Awareness of global warming, environmental problems and an energy crisis}

In Teesside, one group expressed very strong concerns about the fossil fuels crisis, carbon emissions and environmental pollution. They indicated that while these issues were not having an immediate impact on their own daily lives, they were worried that their children's and grandchildren's lives would be negatively affected. For example:

In our lifetime maybe the changes are going to be relatively small. But when we read about what could be happening in 40 years time, 30 to 40 years, it's horrifying to think about our grandchildren. (Teesside, Group 1, male)

In the second Teesside group, one man commented:

You are talking to people, do you think that the environment is getting in a worse state? I think at my age I am realising that. I think it's our younger generation that are going to come through, the kids ...

Another man interjected:

I know about it ... My 10 year old probably thinks that everything's absolutely fine and when she gets to 30 and she starts having a family, is she going to think the same? Is she going to be alert to it, and is it going to be too late by then?

There was group agreement that 'something must be done' about this, especially at international level.

In both groups in Wales, high levels of concern about the environment were expressed; each spontaneously mentioned the need to develop 'alternative' and renewable energy sources. Central government was identified as the crucial 
agent to bring about large-scale change, but there was recognition that individuals had to change their lifestyles - most people believed that cost pressures would eventually force individuals to change their behaviour in energy use.

In London, the group comprising young people (aged 16-25) was especially concerned about global warming and the international dimensions of pollution and energy crises. They advocated much stronger programmes of energy conservation and recycling, and major changes in people's attitudes to transport. However, most agreed that energy issues were not equally salient for everyone, and that people could not be forced to change their behaviour unless price was the crucial factor. The two other groups in London identified problems with global warming and the decline of fossil fuels. One group were critical of 'vested interests' preventing radical innovations; the other group agreed that people generally were aware of environmental problems but were unwilling to change their own behaviour. In this London group, a male participant said:

I think people are aware, but they are not, at the end of the day, being aware and actually doing something about it. They are interested in different things aren't they? But I think most people ... say 'I know about global warming, but I'm not going to stop driving my car'.

Costs and taxation were seen as the most likely instruments to induce change in energy use, and several members referred to the impact of the London congestion charges and higher taxation on polluting vehicles. In the third London group, one male participant argued that expecting the public to alter their environmental behaviour when private corporations continued unchecked was ineffective:

In terms of individuals, I'm not sure that changing everybody's how they use energy in this country is going to be much different if the way business and industries uses and disposes of energy and waste isn't changed first, because that's much greater. Industry is throwing out a lot more waste than ordinary people are.

Much later in this group's discussion, when considering the promotion of hydrogen fuel-cell buses, a man commented about a potential disjunction between people's immediate health priorities and global environmental concerns:

It's no good saying you're going to save the planet, they [the general public] don't give a toss about saving the planet - they care about saving their lungs, they care about what's happening to their kids. And it's better to be selling things that matter to people ... saying that this bus is healthy, it isn't polluting your kids, asthma and all this.

Another participant immediately followed this up by indicating the need for some collective or universal benefits to be demonstrated: "What will "sell" 
this is if we can find ways and means for it to be available to all, and that will "sell" it'.

\section{Responsibility for initiating behaviour change}

In terms of locating responsibilities for taking action to improve energy use, and the question of duties and obligations, opinion was divided across all the focus groups in all the areas. For many participants, central and local government were seen as needing to provide leadership and to take responsibility for initiating energy conservation and encouraging the takeup of new 'green' technologies, in order to achieve the necessary large-scale and long-term changes required. At the same time, individuals were seen as the ultimate source of action, but changes in behaviour were mainly seen as resulting from self-interest, linked with direct threats caused by large increases in fuel prices, for example, and/or financial incentives to move to new technologies. For a significant minority in each of the focus groups, there was scepticism about whether people would make changes voluntarily, and doubts about whether people would be motivated by wider solidaristic goals.

To illustrate this, from the second Teesside group, one man commented:

Well when I think about the environment I look at it from a personal and local perspective rather than globally. Because no matter what we do here, somebody else somewhere ... might do something totally different which negates what we're doing here. So I look to the fact that my living environment is clean. If it's good for me, then it's up to everybody else to clean theirs.

A woman in the same group, discussing recycling schemes, said that 'there is a shocking amount of apathy where I live certainly, and they [other residents] can't be bothered'. She went on to say that residents should be penalised by higher council taxes if they did not participate in recycling. Other focus group members supported her view that in some neighbourhoods, people were not joining in with the scheme, and they were critical of this apathy and nonparticipation. Later in the discussion, a man observed:

If you ask me about responsibility, as a parent I'm responsible to my daughter and children about all sorts. I think there is responsibility for each and every one of us as well, individually ... Erm, but I also think the responsibility's for the next generation to do something about it as well, and not just think it's someone else's responsibility.

In a different Teesside group, when discussing polices which might reduce energy consumption and facilitate wider public involvement, one woman stressed the need for greater commitment by people. Another then said 'You can't bludgeon people into your way of thinking ... Society is interdependent surely, and whatever one person does there is ramifications for the next?' Later, having discussed variations in individuals' and companies' adherence to 
environmental health laws, and problems in encouraging the adoption of new energy-saving technologies, a woman noted:

I still feel though that one of the important points has got to be about wastefulness, because there is sort of an enlightenment that science can provide for everything without personal responsibility for a change in our ways, and I think that has got to be addressed too. So it's fine and dandy coming up with new technology, but you've got to say 'Well look at this, this is the cost, as well as this is what you've got to do'. It's alright having rights but you've got to have responsibilities too, and I think that's what we've got to be careful of.

Another woman immediately followed this up by saying 'I think rights and responsibilities goes through life anyway. You know, that's standard for me.' Another woman then said: 'There will always be people who care, and people who really don't care. And I don't think you'll ever get round to the ones who don't care.'

Similar views were expressed in each of the two focus groups in Wales, and there were some instances where caution was expressed about the willingness of people to modify their behaviour (to become more environmentally oriented). After discussing general levels of awareness of issues such as global warming and the energy crisis, and whether people were prepared to change their own patterns of energy use, in Group 1, one woman commented:

Yes, and they say something should be done, but it's always by somebody else. They don't think they can make any difference themselves. And as well, if somebody says 'Well, do recycling', they say 'Oh, I can't be bothered with that'. That sort of attitude as well, that's what I get.

A few minutes later, a woman suggested that many people are reluctant to acknowledge the seriousness of the wider environmental problems and 'push it aside' and a man agreed with her, commenting:

They're not going to worry about whether the ozone layer's breaking down, or climate change or whether the ice cap's melted. You know they're too wrapped up in getting by from day to day, you know.

Later still, there were some more positive expectations that people could be persuaded to engage in 'green' actions. One woman argued that energy policy initiatives would succeed if they came from the 'grassroots', so that 'people realise that they as an individual can make a difference, and it's getting over that hump of what an individual can do'. As the debate continued, however, this was countered as one man questioned the impact of local environmental and energy-saving schemes, and argued instead for more job creation to combat local unemployment:

I'd rather see 10 factories ... keeping people in work ... Now I'd rather have my gas on or my energy, my lights on, than a few little doves running around ... I'm 
not being funny about it - sometimes you've got to take a step back and say 'Listen, we haven't got a choice here folks, this is what we're going to do'.

The second focus group in Wales predominantly emphasised that it is economic constraints and incentives that would most affect people's decision to adopt new energy technologies and more 'environmentally-friendly' lifestyles rather than some generalised commitment to collective or global welfare. One man claimed that:

We are doing too little too late, and if you want to make a difference then you have got to do it by yourself. You have got to change yourself.

This was immediately followed by a woman who observed:

... but the trouble is the individual person, they don't know - say they want to save the environment, but how much is it going to cost?

Later in the meeting another man challenged the belief that most people were sufficiently concerned about the environment and energy. He said:

It's very difficult to know what proportion of the population really care about these things ... I don't know what the public, what proportion of the public really care.

A woman then immediately observed: 'I think they [the public] don't understand the seriousness of it'. This provoked a debate about the influence of the mass media, conflicting advice from scientists and experts, and the importance of school-level education about these issues. Throughout the exchanges, most in the group seemed to agree that cost factors will probably determine people's acceptance of new energy systems: wider environmental or 'public good' objectives were seen as less immediately relevant in everyday lives.

\section{Attitudes to hydrogen energy technologies}

After the general discussion, focus group participants were shown slides and other visual material about hydrogen energy systems. These explained basic features of hydrogen as an energy carrier, and also showed images of hydrogen fuel-cell vehicles, production facilities and other demonstration projects and prototypes, as well as methods of storage and distribution. Levels of awareness were relatively low in each of the three areas even though the localities in which the focus groups were held contained either large-scale production facilities, or proposals for major development schemes using hydrogen, or demonstrator hydrogen buses. In general, most participants adopted neutral views about the desirability of a shift toward hydrogen energy systems. While some concerns about safety were expressed, these were not overwhelmingly strong. Most people wanted to be given much more detailed information about the 
likely benefits, costs and risks of such technologies. Many also asked searching questions about the relative efficiency and costs of hydrogen compared with other energy sources and carriers.

On questions of production, one man in Teesside asked:

How efficient is electrolysis ... how much carbon do you actually need to produce hydrogen from water?

Another in a different Teesside group asked:

There are lots of uses for hydrogen once you've got it, but where do you get it from, how do you produce it and how much does it cost to produce it?

Similarly, a woman in Wales asked: 'How does it compare with other fuels?' In the other Wales group, a woman asked: 'Is it [transportation] the most effective use of hydrogen in terms of fuel?'

In all the focus groups people questioned whether a shift to hydrogen would really help solve energy and environmental problems. Many asked numerous questions about the practical applications and use of hydrogen technologies. It was evident from the discussion that before indicating whether they were prepared to approve or support hydrogen, people expected much more information about what one referred to as 'the bigger picture'. Support was highly conditional and dependent upon their perception of the seriousness of the energy crisis, and also immediate local circumstances such as unemployment, regeneration or air pollution.

People's views about possible future hydrogen applications such as in vehicles, combined-heat-and-power systems or portable devices were firmly placed in a context of 'trade-offs' between personal cost, convenience and safety. Environmental and global benefits appeared to be low in their list of priorities. Instead the direct impact on their own household expenditure appeared their major concern.

For example, as one man on Teesside commented:

people on the street... they are interested in what the bill is at the end of the month or quarter or whatever it is.

In Wales, one man suggested that:

I don't think people would want to know the detail [of how hydrogen technologies work] but if they could be reassured and believe it was economical [then they would accept them].

In London, a man observed:

People vote with their wallets you know. If hydrogen is going to be a lot cheaper than petrol then they are going to use hydrogen. 
A woman in the same London group, discussing whether hydrogen systems would be acceptable, commented:

if it's not going to disrupt their lifestyle too much, if it's not going to be too costly for them. Because it sounds like in the end the general public would say 'How much is that going to cost me?'

Overall, there was a consistent emphasis that to gain acceptance and support, hydrogen technologies would first have to show demonstrable benefits to consumers in terms of cost and practicality. Potential environmental benefits for the wider community were only of secondary concern.

\section{Conclusions}

There were some variations within and between the focus groups in their reported beliefs about and attitudes towards environmental and sustainability issues. But there are also some dominant themes which recurred in each area. First, there was a recognition that global warming, climate change and energy use were serious problems which confronted individuals and nation-states. Second, however, there was a kind of dissonance between people's acknowledgement of the problems and challenges, and their willingness or capacity to adjust their behaviour. This was expressed in several ways. One concerns the tension between individual self-interest and collective or solidaristic benefits. Some people indicated that they might try to alter their consumption or approve stricter environmental controls if it was beneficial to their own and their children's health, but their concern for 'global' matters, or even other regions of the country, was more limited or even absent. Similarly, many suggested that they might adopt more environment-friendly practices, but could not (or would not) rely on other people to do the same, so this was a deterrent - the classic problem of collective action. Another aspect of people's reluctance to radically change their behaviour concerned their cynicism - or perhaps, more accurately, fatalism - about business and governmental interests. It was frequently noted that innovation and change needed leadership from government, but this was counterbalanced by some opposition to 'vested interests' and support for more 'grassroots' action. Finally, another dominant theme emerged from each of the focus groups: economic factors were highly significant in people's approach to environmental and energy issues. Thus, people's interest in, and willingness to adopt, new energy systems and technologies were heavily influenced by considerations of cost or price. Many were also cautious about the potential trade-offs between economic growth and employment, and more rigorous environmental and energy controls.

These findings indicate that despite the apparent 'green' promise represented by advocates of hydrogen energy, public attitudes towards it are neutral or non-committal. But they are also not shaped by altruistic concern for the wider public good. These attitudes are in line with many previous studies 
about environmental beliefs and behaviour, and in many ways are consistent with the views reported 10 years ago by Macnaghten and Urry (1998). Clearly environmental risks and energy issues have become more problematic at national and international levels, and people's general awareness of them is substantial and growing. There is a consciousness of the importance of energy resources and potential ecological crises, and some acknowledgement that these have an immediate impact upon lifestyles and general sustainability. People generally are conscious that their patterns of consumption, lifestyles and living standards are constrained by structures and processes which they usually regard as beyond their immediate control. The qualitative case-study evidence described here indicates that, while there may be a conditional or provisional recognition of environmental rights and responsibilities, this cannot be characterised as a fully-fledged 'environmental citizenship'. Sustainability may have been identified as a worthwhile goal, and as having resonance with the notion of a 'common good', but there were few signs in focus group discussion that people's collective welfare was the primary objective. Instead, attitudes seemed to converge on instrumental and privatised outlooks, with an improved environment or greater energy efficiency being seen as desirable for individuals and households. Environmental and energy threats were acknowledged, but they tended to be seen as 'distal' concerns, remote from immediate practical action. The responsibilities inherent in ecological citizenship were salient for only some participants, but their practice was contingent on many other factors.

Dobson (2003) and Dobson and Bell (2006) argue that ecological or environmental citizenship requires acceptance and endorsement of collective values and solidaristic objectives, but in this case of attitudes towards energy and new energy systems, there is little evidence of a shared (perceived) community of interests. In considering energy and the environment, people's material well-being is dependent on access to scarce (and depleting) energy sources, and energy itself is commodified, but this common interest is only constituted at an abstract and 'macro' level. It is the expediency of everyday life, and the immediacy of localised conditions, that appear to shape people's beliefs and action about energy, whether based on conventional fossil fuels or on the hydrogen economy. In this field at least, environmental citizenship remains latent and ecological citizenship has yet to evolve.

\section{Acknowledgements}

This research was funded by EPSRC as part of the 'Supergen' programme and its UK Sustainable Hydrogen Energy Consortium (UKSHEC). The authors are grateful to the focus group participants, and to local authorities in Teesside and Wales, as well as the London Sustainability Exchange.

\section{References}

Barbour, R.S. and Kitzinger, J., 1999. Developing focus group research. London: Sage. Barry, J., 1999. Environment and social theory. London: Routledge. 
Barry, J., 2006. Resistance is fertile: from environmental to ecological citizenship. In: A. Dobson and D. Bell, eds. Environmental citizenship. London: MIT Press, 21-48.

Beck, U., 1992. Risk society: towards a new modernity. London: Sage.

Beck, U., 1995. Ecological politics in an age of risk. Cambridge: Polity Press.

Bell, D., 2005. Liberal environmental citizenship. Environmental Politics, 14 (2), $179-194$.

Bergland, C. and Matti, S., 2006. Citizen and consumer: the dual role of individuals in environmental policy. Environmental Politics, 15 (4), 550-571.

Bloor, M., Frankland, J., Thomas, M., and Ronson, K., 2001. Focus groups in social research. London: Sage.

Christie, I. and Jarvis, L., 2002. How green are our values? In: J.A. Park, J. Curtice, K. Thomson, L. Jarvis, and C. Bromley, eds. British social attitudes: the 18th report. London: Sage, 113-152.

Dahrendorf, R., 1994. The changing quality of citizenship. In: B. van Steenbergen, ed. The condition of citizenship. London: Sage, 10-19.

Dean, H., 2001. Green citizenship. Social Policy and Administration, 35 (5), 490-505.

Dickens, P., 1992. Society and nature: towards a green social theory. Hemel Hempstead: Harvester Wheatsheaf.

Dobson, A., 2003. Citizenship and the environment. Oxford: Oxford University Press.

Dobson, A., 2006. Ecological citizenship: a defence. Environmental Politics, 15 (3), $447-451$.

Dobson, A. and Bell, D., 2006. Introduction. In: A. Dobson and D. Bell, eds. Environmental citizenship. London: MIT Press.

Dobson, A. and Valencia Saiz, A., 2005. Introduction. Environmental Politics, 14 (2), $157-162$.

European Hydrogen and Fuel Cell technology Platform, 2005. Strategic research agenda [online]. July. Available from: http://www.HFPeurope.org/uploads/677/686/HFP SRA004_SRA-report-final_22JUL2005.pdf [Accessed January 2006].

Flynn, R., Bellaby, P., and Ricci, M., 2006. Risk perception of an emergent technology: the case of hydrogen energy [online]. Forum for Qualitative Research/FQS, 7 (1). Available from: http://www.qualitative-research.net/fqs/fqs-e/inhalt1-06-e.htm.

Hayward, T., 2006a. Ecological citizenship: justice, rights and the virtue of resourcefulness. Environmental Politics, 15 (3), 435-446.

Hayward, T., 2006b. Ecological citizenship - a rejoinder. Environmental Politics, 15 (3), 452-453.

Hennicke, P. and Fischedick, M., 2006. Towards sustainable energy systems: the related role of hydrogen. Energy Policy, 34, 1260-1270.

Hobson, K., 2001. Sustainable lifestyles: rethinking barriers and behaviour change. In: M.J. Cohen and J. Murphy, eds. Exploring sustainable consumption: environmental policy and the social sciences. Oxford: Elsevier/Pergamon, 191-209.

Hobson, K., 2003. Thinking habits into action: the role of knowledge and process in questioning household consumption practices. Local Environment, 8 (1), 95-112.

Irwin, A., 2001. Sociology and the environment. Cambridge: Polity.

Macnaghten, P. and Urry, J., 1998. Contested natures. London: Sage.

McDowall, W. and Eames, M., 2006. Forecasts, scenarios, backcasts and roadmaps to the hydrogen economy: a review of the hydrogen futures literature. Energy Policy, 34, 1236-1250.

Murphy, J. and Cohen, M., 2001. Sustainable consumption: environmental policy and the social sciences. In: M.J. Cohen and J. Murphy, eds. Exploring sustainable consumption: environmental policy and the social sciences. Oxford: Elsevier/Pergamon, 225-249.

Nash, N. and Lewis, A., 2006. Overcoming obstacles to ecological citizenship. In: A. Dobson and D. Bell, eds. Environmental citizenship. London: MIT Press, 153-184.

Newby, H., 1991. One world, two cultures: sociology and the environment. Network, British Sociological Association, 50 (May). 
Newby, H., 1996. Citizenship in a green world: global commons and human stewardship. In: M. Bulmer and A. Rees, eds. Citizenship today: the contemporary relevance of T.H. Marshall. London: UCL Press, 209-222.

Ricci, M., Bellaby, P., and Flynn, R., 2007a. Stakeholders and publics' perceptions of hydrogen energy technologies. In: R. Flynn and P. Bellaby, eds. Risk and the public acceptance of new technologies. Basingstoke: Palgrave-Macmillan, 175-197.

Ricci, M., Newsholme, G., Bellaby, P., and Flynn, R., 2007b. The transition to hydrogen-based energy: combining technology and risk assessments and lay perspectives. International Journal of Energy Sector Management, 1 (1), 34-50.

Rifkin, J., 2002. The hydrogen economy. New York: Tarcher/Putnam.

Sustainable Development Commission, 2006. I will if you will: towards sustainable consumption [online]. Report by Sustainable Consumption Roundtable, 1 May. Available from: http:www.sd-commission.org.uk/publications.php?id=367 [Accessed 28 August 2006].

Turner, B.S., 1990. Outline of a theory of citizenship. Sociology, 24 (2), 189-217.

Turner, B.S., 2001. The erosion of citizenship. British Journal of Sociology, 52 (2), 189-209.

United Nations Environment Programme, 2006. The hydrogen economy: a non-technical review [online]. New York: United Nations. Available from: www.unep.org [Accessed 24 August 2006].

van Steenbergen, B., 1994. Towards a global ecological citizen. In: B. van Steenbergen, ed. The condition of citizenship. London: Sage, 141-152.

Yearley, S., 2005. Cultures of environmentalism. London: Palgrave Macmillan. 